\title{
Knowledge, Repetition and Power in Ibn al-'Arabi's Thought: Some Preliminary Comments on Methodology
}

\author{
Ali Balc1 \\ Sakarya University
}

\begin{abstract}
This paper's major motivation is to contribute to the debate on how international relations (IR) scholars can develop an alternative method for studying power. A focus on Islamic Sufi thinker Ibn Al- 'Arabi is suggested to demonstrate the early philosophical conceptualization of power relations in a non-Western context. For Ibn Al-'Arabi, in a world in which unrepeatability is the rule, creating repeatability and fixation through interpretation is certainly done for worldly purposes. His work suggests that any attempt to understand "the cosmos" is an arbitrary intervention, which strictly reflects power relations among actors. Therefore, Ibn Al-'Arabi's work can trigger scholarly questions on not only methodology but also on the sociology of the IR discipline and foreign policy in a non-Western context. His arguments can be utilized in critical and poststructuralist conceptions of power in IR.
\end{abstract}

Keywords: Ibn al-'Arabi, the cosmos, knowledge, repetition, interpretation, delimitation, power

\section{Introduction}

This paper was inspired by the lack of non-Western theory/method in Turkey's social sciences. Because of the ambient air of Western texts in formal education, non-Western alternatives in the field of theory/method have been forced into silence (or to the margins) for a long time. As a result, non-Western scholars in Turkey, such as my colleagues and I, have borrowed Western theories/methods in order to understand our own politics and society. However, I believe that this is the case not because of the excellence of Western social science but because the scope of Western theory/method matches the scope of Western hegemony over the rest of the world. As an academic, I am not immune to this relation of domination simply because I write in English and heap my intellectual basket with Western texts. It is a paradox for me that Western texts haunt my mind when I read a non-Western text, by which I mean a text which came out in a world where there was no Western political or intellectual hegemony. I study the concept of power, power relations, and criticism of realist thinking. I, as a reader of Western critical thinkers, developed the following questions: Where should we look to in accounting for the exercise of temporal power? How does temporal power realize itself? If there is nothing but knowledge (or text) at hand, then can it be said that power rests in knowledge? What is the relation between knowledge and its repetition in other texts in terms of power? In this article, I focus on work by Islamic Sufi thinker Muhyi al-Din 
Muhammad ibn 'Ali Ibn al-'Arabi (1165-1240) because I think his work can shed light on the early philosophical roots of understanding power relations in Islamic and non-Western contexts. In fact, new questions came to my mind throughout reading Ibn al-'Arabi: What is the driving force behind this interpretation, fixation, and repetition respectively? How are these repetitions distributed in a specific historical period? Do these intractable repetitions say anything to us?

Building on Ibn al-'Arabi's work, I argue that it is not knowledge itself but its repeatability or the repetition of knowledge that is the engine of temporal power. Therefore, any research that aims to illustrate the exercise of temporal power should focus on the repetition and dissemination of knowledge through texts (and images). For Ibn al-'Arabi, repetition creating fixations/laws is arbitrary since the ultimate rule of the universe is the unrepeatability of things. Ibn al-'Arabi also gives importance to interpretation ( $t a$ 'wil) in the realization of temporal power. For him, it is only interpretation that makes temporal power possible. Interpretation is the process that makes ever-changing and unrepeatable things fixed and repeatable, on which temporal power bases itself. Ibn al-'Arabi's thought on power has many similarities with that of poststructuralist thinkers of our own time. Then why do we, as nonWestern academics, build our theoretical claims on Western thinkers' thought?

While I acknowledge the seminal work on the parochialism of Western IR and its implications, my preliminary work in this article aims to return to authentic texts in existence prior to the domination of Western philosophy. ${ }^{1}$ Indeed, there have been studies on "referential homegrown theory building" and early theory attempts by Chinese and Indian thinkers. ${ }^{2}$ For example, as one of the ways to "building IR theory with Chinese characteristics" - as it is often termed in discussions - Chinese thinker Hsun Tzu (Sun Tzu or Xun Zi) and his political teachings are considered a source for understanding and explaining Chinese foreign policy behavior. ${ }^{3}$ His thoughts on types of great powers and international order especially inspired frameworks to explicate China's "peaceful rise." 4 Based on Xun Zi's conceptions of power, Yan builds a formula to differentiate forms of power and their contributions to the nation's "comprehensive power."

Likewise, the arguments of Ibn al-'Arabi's works can be utilized in critical and poststructuralist conceptions of power in IR. Therefore, the aim of this article is to illustrate

Stanley Hoffmann, “An American Social Science: International Relations,” Daedalus 106, no. 3 (1977): 45; Kal J. Holsti, The Dividing Discipline (Winchester, Mass.: Allen \& Unwin, 1985); Howard Wiarda, "The Ethnocentrism of the Social Science: Implications for Research and Policy," The Review of Politics 43 (1981): 163-97; Robert M.A. Crawford, "Where Have All Theorists Gone - Gone to Britain? Everyone? A Story of Two Parochialisms in International Relations," in International Relations-Still an American Social Science?: Toward Diversity, ed. Robert M.A. Crawford and Darryl S.L. Jarvis (Albany: SUNY University Press, 2001), 222-23; Tony Smith, "Requiem or New Agenda for Third World Studies," World Politics 37, no. 4 (1985): 532-62; Gayatri C. Spivak, "Can the Subaltern Speak?" in Marxism and the Interpretation of Culture, ed. C. Nelson and L. Grossberg (Champaign, IL: University of Illinois Press, 1988), 217-313; Ole Wæver, "The Sociology of a Not So International Discipline: American and European Developments in International Relations," International Organization 52, no. 4 (1998); Amitav Acharya, "Dialogue and Discovery: In Search of International Relations Theories Beyond The West," Millenium: Journal of International Studies 39, no. 3 (2011): 619-37; Amitav Acharya and Barry Buzan, "Why is There No Non-Western International Relations Theory? An Introduction," International Relations of the Asia-Pacific 7, no. 3 (2007): 287-312; Navnita Chadha Behera, "Re-imagining IR in India," International Relations of the Asia-Pacific 7, no. 3 (2007): 341-68.

For similar attempts in referential homegrown theory building, its promises, and possible shortcomings, see Gonca Biltekin, "Batı-dışı Uluslararası İlişkiler Teorileri ve Özgün Kuram," in Uluslararası Illişkiler Teorileri, ed. Ramazan Gözen (İstanbul: İletişim, 2014), 517-64.

Dawa Norbu,“Tibet in Sino-Indian Relations: The Centrality of Marginality," Asian Survey 37, no. 11 (1997): 1084; Yan Xuetong, Ancient Chinese Thought and Modern Chinese Power (New Jersey: Princeton University Press, 2011).

4 Yan Xuetong, "Xun Zi's Thoughts on International Politics and Their Implications," Chinese Journal of International Politics 2, no. 1 (2008): 135-165.

5 Xuetong, "Xun Zi's Thoughts," 161. 
the possibility of studying power in a non-Western way. Unfortunately, I am not well versed in Arabic and thus this text would not have appeared without two great translators of Ibn al-'Arabi. William G. Chittick's abridged translation made al-Fütuhat al-Makkiyya known to English readers ${ }^{6}$ and Ekrem Demirli's meticulous translation of the Fütuhat into Turkish requires a great debt of gratitude. ${ }^{7}$ This paper is mostly based on Fütuhat and composed of three sections. First, I attempt to show why repeatability is arbitrary by focusing on Ibn al-'Arabi's perception of the cosmos and Allah. Second, I explain why repetition amounts to delimitation and fixation. In the last section, I focus on the relation between the jurist (interpreter) and the king to illustrate the fact that it is interpretation that makes temporal power possible.

\section{The Cosmos and Unrepeatability}

The cosmos (alam) is the manifestation of the Divine Presence because everything that exists in this cosmos or universe manifests something from Allah, who prefers to reveal Himself in this way. As Chittick says, for Ibn al-'Arabi, the cosmos is not the He; rather it just manifests the He. ${ }^{8}$ The universe is not for the manifestation of He himself, but is the effects and properties of Allah's divine names. Ibn al-'Arabi concludes that "in respect [to] Himself, He is 'independent of the worlds', but in respect [to] His Most Beautiful Names, [they] demand the cosmos because of its possibility (imkan)...for their effects to become manifest within it." In other words, the cosmos is "His locus of self-disclosure, within which the properties of His names may become manifest." 10 This means that "although Allah is out of the cosmos, He demands the cosmos for His Most Beautiful Names." "What Ibn al-"Arabi says on this issue is worth quoting at some length:

[Allah] brought the cosmos into existence only so that the cosmos might come to know Him. But the cosmos is temporally originated, so nothing subsists within it that is not temporally originated. Knowledge of [Allah] subsists within the cosmos either through [Allah]'s giving knowledge (ta'rif), or through the faculty which $\mathrm{He}$ created within it through which knowledge of $[$ Allah $]$ is reached, through only in a certain aspect. ${ }^{12}$

Ibn al-'Arabi rejects any knowledge about Allah reached through reason because the only way to know Him is through "a report received from Him." 13 "Since It is not similar to anything in the cosmos, nor is anything in the cosmos similar to It," thing that follows "the authority of another created thing" in the cosmos has nothing to know of Allah. ${ }^{15}$ In other words, the cosmos manifests Him but only to the extent of what "He says about Himself." 16

Having said that the cosmos manifests Him, Ibn al-'Arab immediately refuses the repetition of things within the cosmos. For him, "no attribute and no state in the cosmos

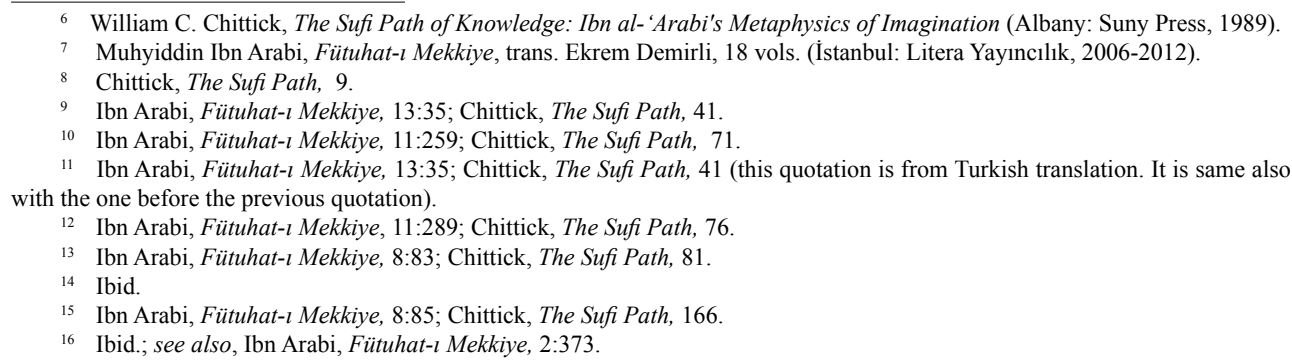

16 Ibid.; see also, Ibn Arabi, Fütuhat-l Mekkiye, 2:373. 
remains for two moments, nor does any form become manifest twice." ${ }^{17}$ This is the case because "Allah never discloses Himself in a single form twice, nor does He create similarity in two individuals because of the Divine Vastness." ${ }^{\prime 18}$ For Ibn al- Arabi, the Divine Vastness (al-tawassu' al-ilahi), the infinity of possible things, forbids repetition because "the Divinity is so vast that it cannot be repeated" "19 and Allah is "too exalted to disclose Himself in a single form twice or [as] two individuals." ${ }^{20}$ Why is that the case? Ibn al-"Arabi explains "the cosmos is never fixed in a single state for a moment since $[$ Allah $]$ is ever-creating constantly. Were the cosmos to remain in a single state for two moments, it would be described by independence from [Allah]." ${ }^{21}$ Ibn al-"Arabi offers another explanation on this: "[Allah] does this so that the entities will be poor and needy toward [Allah] at each instant." 22 This need is what shapes the relation between Allah and all created things. The repetition in different moments or an existence of the similar for two moments or more would make entities something "qualified by independence from [Allah]." ${ }^{23}$ Therefore, Allah "creates perpetually at each instance"24 and the lack of repetition is the governing rule of the cosmos. As a result, for Ibn al-'Arabi, "he who knows the Divine Vastness knows that nothing is repeated in existence." 25

In such a cosmos where actual fact "has never any fixity in a single state" or unrepeatability is the rule, the "actual situation cannot be apprehended by reason or the eye." 26 There is no base or fixity on which reason can start to consider Allah. Therefore, "when a person rationally considers [Allah], he creates what he believes in himself through his consideration." ${ }^{27}$ This consideration-cum fixity about the knowledge of Allah becomes open to repetition. For Ibn al-"Arabi, this is not Allah itself because "the Divine Vastness... disappear[s] through repetition of the affair." ${ }^{28}$ But, on the other hand, "it has been established for us that there is no repetition in the Divine Side." ${ }^{29}$ Because of this non-repetitiveness in the Divine Side, it is impossible to comprehend Allah through reason. Then, for Ibn al-'Arabi, every attempt to comprehend Him is "nothing but passage from veil to veil." ${ }^{30} \mathrm{He}$ continues that "reason cannot delimit Him by one of those forms, since He destroys that limitation by the next selfdisclosure. ${ }^{\prime 31}$ As a result, all attempts to fix a sign onto Allah or to somehow tie It to reason's own finite perspective say nothing about Allah but about those who create Allah through their considerations.

Accordingly, Ibn al-'Arabi's ontological position resembles that of Plato, in the sense that actuality is the partial manifestation of reality. There is one crucial difference, though.

17 Ibn Arabi, Fütuhat-ı Mekkiye, 9:251; Chittick, The Sufi Path, 99.

18 Ibn Arabi, Fütuhat-l Mekkiye, 2:78 (this quotation is from the Turkish translation). See also, Ibn Arabi, Fütuhat-l Mekkiye, 2:180; For Ibn al-'Arabi, "the root of all things is difference (tefrika) (Ibn Arabi, Fütuhat-l Mekkiye, 9:300; Chittick, The Sufi Path, 67). He explains the impossibility of similarity by saying the following: "if there is similarity in the facts, nothing would be different from those which are said as similar... the thing which differentiates it from the others is the thing itself" (Ibn Arabi, Fütuhat-l Mekkiye, 2:180; see also, Ibn Arabi, Fütuhat-l Mekkiye, 16:56). However, he warns us that the difference or "what separates two similar things is difficult to comprehend through witnessing" (Ibn Arabi, Fütuhat-l Mekkiye, 9:251).

19 Ibn Arabi, Fütuhat-ı Mekkiye, 8:316 (this quotation is from Turkish translation).

20 Ibn Arabi, Fütuhat-ı Mekkiye, 10:239; Chittick, The Sufi Path, 111.

21 Chittick, The Sufi Path, 98; see also, Ibn Arabi, Fütuhat-l Mekkiye, 10:190.

22 Ibid; see also, Ibn Arabi, Fütuhat-ı Mekkiye, 12:345.

23 Ibn Arabi, Fütuhat-ı Mekkiye, 10:190; Chittick, The Sufi Path, 98.

24 Ibid.

25 Ibn Arabi, Fütuhat-ı Mekkiye, 9:74; Chittick, The Sufi Path, 104.

26 Ibn Arabi, Fütuhat-ı Mekkiye, 15:30; Chittick, The Sufi Path, 231.

${ }_{27}$ Ibn Arabi, Fütuhat-ı Mekkiye, 16:46; Chittick, The Sufi Path, 350; see also, Ibn Arabi, Fütuhat-ı Mekkiye, 8:360; Chittick, The Sufi Path, 232.

${ }_{28}$ Ibn Arabi, Fütuhat-ı Mekkiye, 2:30; Chittick, The Sufi Path, 219.

29 Ibid.

30 Ibn Arabi, Fütuhat-ı Mekkiye, 15:297; Chittick, The Sufi Path, 230.

31 Ibn Arabi, Fütuhat-ı Mekkiye, 15:30; Chittick, The Sufi Path, 231. 
While Plato's ideas serve as constant and absolute essences of actuality, the Divine Vastness of Allah make such essence everchanging. For a researcher whose concern is to understand only the cosmos (or actuality), not Allah per se, is that such ontology severely limits even modest generalizations. How this ever-changing quality of the cosmos is to be understood is the subject of the next section, as social research ultimately requires an inference about social phenomena involving actors' behavior and/or socially constructed structures.

\title{
3. Repeatability and Delimitation
}

The lack of repetition (takrar) means that Allah never displays Himself twice in exactly the same way. ${ }^{32}$ If the cosmos reflects the Divine Vastness in which there is no repetition, then it can be concluded that repetition is an illusion created by reason. Because the cosmos as a place of manifestations is something that constantly fluctuates, reason as a fetter is dismissed by Ibn al-'Arabi in his understanding of it. Reason prevents the cosmos from fluctuating and thus opens a space for repetition. In short, repetition is closely related to reason. Ibn al-'Arabi explains this by comparing the heart with reason. Unlike the heart, which is in "constant fluctuation" because "it does not remain [fixed] in a single state," reason "delimits." ${ }^{33}$ When he says "the heart is His Throne and not delimited by any specific attribute," ${ }^{34} \mathrm{Ibn}$ al-"Arabi attributes fluctuation to the heart and fixity to rational thought ( 'aql). He says:

\begin{abstract}
The reality in existence lies in variegation (telvin)... The heart longs to witness this reality. [Allah] made the heart the locus of this longing to bring the actualization (tahsil) of this reality near to man, since there is fluctuation in the heart.[Allah] did not place this longing in the rational faculty since reason possesses delimitation. If this longing were in the rational faculty, the person might see that he is fixed in a single state. But since it lies in the heart, fluctuation comes upon him quickly. ${ }^{35}$
\end{abstract}

For Ibn al-'Arabi, the meaning of the word for 'reason' ('aql) derives from the word for 'fetter' ('iqal), which is why "reason comes from the world of delimitation... it obviously and necessarily belongs to the world of delimitation, in contrast to the heart." ${ }^{36}$ As for how this delimitation occurs, Ibn al-'Arabi argues that since "there is nothing in reason by itself," ${ }^{37}$ unlike the heart, what reason knows derives from its characteristic of acceptance (or interpretation). This is why reason restricts infinite possibilities to its own interpretation ${ }^{38}$ (or the one accepted). When something is accepted as something through rational consideration, it automatically becomes fixed and therefore repeatable. This explains why "repetition amounts to constraint (diq) and delimitation." ${ }^{39}$ Having said this, Ibn al-'Arabi concludes

32 Chittick, The Sufi Path, 96.

33 Ibn Arabi, Fütuhat-l Mekkiye, 2:377; Chittick, The Sufi Path, 111

34 Ibn Arabi, Fütuhat-ı Mekkiye, 11:275; Chittick, The Sufi Path, 107; Therefore Ibn al-'Arabi defines Allah as He/not He (huwa la huwa). See especially, Ibn Arabi, Fütuhat-ı Mekkiye, 13: 386-87; Ibn Arabi, Fütuhat-ı Mekkiye, 9:103; Chittick, The Sufi Path, 114. Like this, the cosmos is defined as "unknown/known." See, Ibn Arabi, Fütuhat-ı Mekkiye, 9:88; Chittick, The Sufi Path, 114.

35 Ibn Arabi, Fütuhat-l Mekkiye, 9:339; Chittick, The Sufi Path, 108 (the first sentence of this quotation is from Turkish translation).

36 Ibn Arabi, Fütuhat-l Mekkiye, 6:429; Chittick, The Sufi Path, 109; see also, Ibn Arabi, Fütuhat-l Mekkiye, 12:101; Chittick, The Sufi Path, 107.

37 Ibn Arabi, Fütuhat-l Mekkiye, 2:375.

38 For Ibn al-'Arabi, the "source of interpretation is... reason" (Fütuhat-l Mekkiye, 9:314). He explains why reason is prone to interpretation instead of truth as the following: Knowledge reached through consideration comes across with suspicion raised again by reason itself through consideration. In this situation, reason has two options; it either gets rid of this suspicion without adding anything to its own previous knowledge or replaces suspicion with previous knowledge. In the second case, suspicion becomes new knowledge. (Fütuhat-l Mekkiye, 12:195).

39 Ibn Arabi, Fütuhat-ı Mekkiye, 10:239; Chittick, The Sufi Path, 111 
that "fluctuation in the heart is equivalent to the self-transmutation in divine forms... for this reason knowledge of the Real (al-Haqq) from the Real is possible only through the heart, not reason." 40

When Ibn al-"Arabi says that those "who professes similarity [have] also delimited and confined Him in [their] declaration of similarity," ${ }^{41}$ he duly emphasizes the role of similarity and repetition in delimiting and confining something. What is the function of this delimitation or binding? For Ibn al-'Arabi, the inevitable result of stabilizing unrepeatability or limiting infinite manifestations is to create a mechanism of control for those who fetter themselves to a single image of Allah. How this control is actualized is as the following:

\footnotetext{
Were the Essence to make the loci of manifestation (mazahir) manifest, It would be known. Were It known, It would be encompassed (ihata). Were It encompassed, It would be limited ( $h a d d$ ). Were It limited, It would be confined (inhisar). Were It confined, It would be owned (mulk). ${ }^{42}$
}

This is where the (earthly) power or property (mülk) emerges. In other words, willing to know (about Allah) is not independent from earthly purposes. For Ibn al-'Arabi, the regulation of unpredictability, the subjugation of infinite manifestations, or imposing predictability upon the cosmos/Allah through rational thinking ('aql) inevitably result in confinement and possession. Therefore, arbitrary construction of repeatability not only makes a scheme of cause and effect possible, but it also evokes dualisms such as good/bad, here/there, superior/ inferior, and before/after, on which stable interpretations are based. ${ }^{43}$ For example, defining Allah as 'immanence' is to privilege your own definition over others. In al-Füsus al-Hikem, Ibn al-'Arabi says the following:

\begin{abstract}
If you insist only on His transcendence, you restrict Him, and if you insist only on His immanence you limit Him. If you maintain both aspects you are right...[w] hile the one who isolates Him tries to regulate Him. Beware of comparing Him if you profess duality, and, if unity, of making Him transcendent. You are not He and you are He and you see Him in the essences of things both boundless and limited. ${ }^{44}$
\end{abstract}

Accordingly, the philosophical roots of alternative understandings of rationality or the logic of reason can be traced back to Ibn al-'Arabi's rejection of knowledge that builds on repetition because of the ever-creating feature of the cosmos. This epistemological skepticism about rationalism and empiricism might help us discuss the absence of a positivist or deductive methodology in the non-Western context. Thus, Ibn al-'Arabi's work is an important contribution to a critical understanding of rationality in a non-Western context, given his arguments above on the relationship between reason and unrepeatability, in which delimitation or dualism is inevitable. The lack of repetition or conscious ignorance on fixation and the emphasis on infinite possibilities in understanding is a serious challenge for a positivist methodology in interpreting social phenomena. For Ibn-Al Arabi, then, repetitions of phenomena, as observed by "the eye" as "facts," and conceptualized by "the mind" as

40 Ibn Arabi, Fütuhat-ı Mekkiye, 2:377; Chittick, The Sufi Path, 112 (this quotation is translated from Turkish version).

41 Ibid; for Ibn al-"Arabi, similar things are for those "who know an outward significance of the present life, but of the next they are heedless" and hence these similarities "are veils upon the eyes of the blind" (Ibn Arabi, Fütuhat-l Mekkiye, 8:316; Chittick, The Sufi Path, 99).

42 Ibn Arabi, Fütuhat-ı Mekkiye, 10:80; Chittick, The Sufi Path, 60.

43 For Ibn al-'Arabi's criticism of those who interpret Allah in one way or another, see Ibn Arabi, Fütuhat-l Mekkiye, 11:52; Chittick, The Sufi Path, 63.

44 Ibn al-'Arabī, The Bezels of Wisdom, trans. Ralph Austin (New Jersey: Paulist Press, 1980), 75 (italics are mine). 
"patterns," are more reflective of power relations between the interpreter and the powerful, than of the cosmos itself.

\section{Interpretation and Temporal Power}

Repeatability makes dichotomies possible, which opens a space for interpretation ( $t a$ 'wil). Why do people interpret things one way or another? To put it differently, what makes it rational to interpret one way rather than another and what makes it rational to advance one conception of Allah rather than another? For Ibn al-'Arabi, interpretation emerges from the relation between the jurist and the king. This is a two-tier process. On the one hand, what prevents people "from ascribing to [Allah] that which is ascribed to Him by the revealed books and the messengers is the lack of justice on the part of jurists (fuqaha), and the possessors of [worldly] authority (ulu'l-amr)". ${ }^{45}$ Since most kings supported exoteric scholars who were "dedicated to the chaff of this world, to the love of position and leadership, and to accommodating the desires of kings", the knowers of Allah "remain in the lowliness of incapacity and constraint like a messenger to whom not one of them believes". ${ }^{46}$ On the other, many people interpret the revealed book in order to gain favor with those in power. On this matter, Ibn al-'Arabi says the following:

\footnotetext{
When the winds of caprice dominate over souls and the learned seek high degrees with kings they leave the clear path and incline toward far-fetched interpretations. Thus they are able to walk with the personal desires of the kings in that within which their souls have a caprice, and the kings can support themselves by a Shari'ite command. It may happen that the jurist (faqih) does not himself believe the interpretation, but he gives pronouncements (fatwa) in accordance with it. ${ }^{47}$
}

Ibn al-"Arabi calls these jurists "exoteric/formalist scholars" who adhere to the knowledge of external forms (ashab 'ilm al-rusum). They are exoteric "because they devote themselves to love for position, emotion for domination over others, sense of being superior over Allah's real servants and will-to-see that the common people need them" ${ }^{48}$ These people are those who "desire to be appointed to posts as judges, notaries, inspectors or teachers in a madrasah". ${ }^{49}$ They also submit to wealthy and powerful one "because of their coveting his wealth and their fear of his power". ${ }^{50}$ A Divine intervention into earthly affairs by the Mehdi will clearly illustrate their biased interpretations and the arbitrary construction of commandments for earthly purposes by these scholars. Therefore, "the Mehdi's coming forth into the world will annihilate any power of domination, exoteric scholars' privilege from the mass of common, and...the differences [among] the commandments". ${ }^{51}$ The last point is worth exploring in greater detail because, for Ibn al-'Arabi, differences among the commandments emerge from interpretation, which is where temporal power realizes itself.

For Ibn al-'Arabi, interpretation emerges from both coercion and consent. On the one hand, the interpreter fears punishment by the possessors of [worldly] authority because of his/her commandment concerning something. On the other hand, the interpreter intentionally

45 Ibn Arabi, Fütuhat-ı Mekkiye, 2:329; Chittick, The Sufi Path, 72.

46 Ibn Arabi, Fütuhat-l Mekkiye, 2:329-30; Chittick, The Sufi Path, 72-3.

47 Ibn Arabi, Fütuhat-l Mekkiye, 11:121; Chittick, The Sufi Path, 202. For an analysis of this point, see Ian Almond, Sufism and Deconstruction: A Comparative Study of Derrida and Ibn'Arabi (London: Routledge, 2004).

48 Ibn Arabi, Fütuhat-l Mekkiye, 13:86 (this quotation is from the Turkish translation).

49 Ibid., 87 (this quotation is from the Turkish translation).

50 Ibid., 87-8 (this quotation is from the Turkish translation).

51 Ibid., 87 (this quotation is from the Turkish translation). 
gives his/her commandment in return for a greater reward by the king. Therefore, there is a tenacious relationship between the [earthly] power and interpretation. In other words, interpretation lies in the core of [worldly] authority/power. Ibn al-'Arabi says that Allah gives exoteric scholars "domination over the creatures through the pronouncements they make", namely interpretations. ${ }^{52}$ Therefore, "the power in the life of this world" belongs to these scholars. ${ }^{53}$ But they are not really in a power position. On the contrary, scholars whose "hearts have been overcome by love for this world and the search for position and leadership" are condemned to come "needy to the doors of ignorant governors and rulers". ${ }^{54}$

Ibn al-'Arabi's discontent with interpretation ( $t^{\prime}$ 'wil) is because the interpreter assumes the authority of reason in judging Divine words. For example, reason distorts things that seem impossible to rational faculties, and therefore "reason's faith [here] is in its own interpretation, not in the report". ${ }^{55}$ This is why people with rational faculties "diverge in accordance with the measure of their consideration" concerning Allah and they accuse each other of not knowing Allah. ${ }^{56}$ Since "interpretation is delimitation", ${ }^{57}$ rational people create a fixation concerning Allah, of whom others have no belief. Consequently, true knowledge of Allah is not something reached through rational thinking, but is instead thrown by Allah into the heart of the knower. ${ }^{58}$ Ibn al-'Arabi strongly condemns those "who are not moderate but instead plunged deeply into interpretation such that no correspondence (munasaba) remains between the revealed words and the meaning". ${ }^{59}$ He says that "the path of salvation for those who have no insight from Allah is not to interpret" 60 and "there is nothing more harmful to the servant [of Allah] than to interpret things". ${ }^{61}$

Accordingly, the arguments of Ibn al- 'Arabi are fruitful for an alternative understanding of interpretations and to an extent, his texts are early examples of the rejection of "explaining" world affairs or social phenomenon so as not to impose power, given the acceptance that the cosmos is a manifestation of the Divine Presence (Allah). In other words, one can perhaps claim that critical and post-structuralist conceptions of power have been in place in a nonWestern context for a long time. Rather than relying on Western critical studies to go beyond a positivist understanding of rationality and a criticism of the realist conception of power, we can utilize such texts in understanding social phenomenon despite its challenges for an alternative methodology. The following section concludes this exploration, with preliminary ideas or questions on how an example of non-Western thought, namely Ibn al-'Arabi's rejection of repeatability or repetition of knowledge (not knowledge itself), can be a subject for studying IR.

\section{Conclusion}

Is it possible to develop a method on tracing power using Sufi thinker Ibn al-'Arabi? This

\footnotetext{
52 Ibn Arabi, Fütuhat-l Mekkiye, 2:351; Chittick, The Sufi Path, 248 (italics are mine).

53 Ibid.

54 Ibn Arabi, Fütuhat-l Mekkiye, 3:35.

55 Ibn Arabi, Fütuhat-l Mekkiye, 2:175; Chittick, The Sufi Path, 201.

Ibid.

57 Ibn Arabi, Fütuhat-ı Mekkiye, 10:90; see also, Ibn Arabi, Fütuhat-l Mekkiye, 8:360; Chittick, The Sufi Path, 71.

58 Ibn Arabi, Fütuhat-l Mekkiye, 2:175; Chittick, The Sufi Path, 170; However, Ibn al-'Arabi does not completely deny interpretation but says that reality reached through interpretation is just a "coincidence" (Ibn Arabi, Fütuhat-l Mekkiye, 9:333). Therefore, he neither rejects the commandment reached through interpretation nor accepts it (Ibn Arabi, Fütuhat-l Mekkiye, 11:94).

59 Ibn Arabi, Fütuhat-l Mekkiye, 10:74; Chittick, The Sufi Path, 201.

60 Ibn Arabi, Fütuhat-ı Mekkiye, 8:109.

${ }_{61}$ Ibn Arabi, Fütuhat-ı Mekkiye, 9:336; Chittick, The Sufi Path, 269.
} 
is a challenging question not only because Ibn al-'Arabi himself did not propose a specific method for studying power but any attempt to talk about such a method bears the risk of distorting what Ibn al-'Arabi really said. His assumption is quite simple: When "constant change of the Root" in the $\operatorname{cosmos}^{62}$ is the rule, delimitation, fixation, and repetition - through which power is exercised - become arbitrary things. While the construction of meaning requires representation, the fixation of this representation in one way or another inevitably necessitates a process of reiteration and repetition. Therefore, there is an immanent relation between meanings and power relations. Fixed meanings are incessantly (re)constructed by centres of power thanks to the latter's ability to control the process of creating representations and govern repetitions in a specific way. Without repetition (and power), representation has nothing to do with meaning.

As a result, I suggest that IR scholars in the non-Western world can engage in innovative ways to apply the readings of early texts on the relationship between meaning and power in three areas of studying social phenomena in world affairs:

1.) Sociology of the discipline: Looking at repetitions in scholarly work. Are citations repetitions of some sort? Who is the jurist and who is the king in citations? Aside from the original and cited authors, how do reviewers, editors, publishing companies, owner institutions, etc. intervene in this repetition process? How does becoming more cited affect one's tenure? What governs intertextuality?

2.) Foreign policy: Repetition and its relationship to temporal power can be studied with respect to repetitions of behaviour and discourse in international affairs. How do repetitions in text, such as speeches, manifestos, party programmes, legal texts, and treaties, as well as in non-verbal media, such as gestures and images, inform temporal power?

How can the relationship between scholars of foreign policy and practitioners of foreign policy be constructed in terms of the jurist/king relationship?

3.) Methodology can be used to problematize rationalist modes of thinking (i.e., based on assumptions about rational actors, as well as knowing about them through reason) in IR, in which regularities and patterns are sought across a wide range of phenomena. Are not concepts immanently delimitative as rather simple descriptions of otherwise illimitable idiosyncrasies? For example, how an assumption of repetition in an actor's behaviour ("This particular decision-maker constantly does the same thing.") furthers or limits that behaviour's explanation.

Ibn al-'Arabi's work proposes a fundamental rule in terms of methodology according to which any researcher who is interested in tracing temporal power should focus on its arbitrariness, which itself is the logical result of the relation between the jurist (researcher) and the king (the targeted actor?). To put this in a formulation, when a researcher interprets, he/ she fixes and delimits; were the thing fixed/delimited, it would be repeated; were it repeated, it would be predicted; were it predicted, it would be governed. Since power operates through a constant repetition of commandment (namely law) and act with the help of researchers, any study of power should focus on the mechanism of the (re)production of fixed things/ meanings.

62 Ibn Arabi, Fütuhat-ı Mekkiye, 12:101; Chittick, The Sufi Path, 107; In Füsus, Arabi says that "the whole cosmos is a collection of accidents; hence it undergoes continual change at every moment, since "the accident does not remain for two moments", (Chittick, The Sufi Path, 97). 


\section{Postscript}

This paper was motivated by the first All Azimuth meeting in Çeşme, İzmir, on 24 May 2013, and was written during the summer of 2013. The participants were from the IR departments of different Turkish universities and we discussed the following question: Is a distinct IR theory possible in Turkey? This question is closely related to the following broader questions: Is non-Western theory possible? Is the voice of non-Western theory audible? My take on this question was based on what Martin Heidegger said in his Der Spiegel interview: "Everything essential and great has only emerged when human beings had a home and were rooted in a tradition". ${ }^{63}$ Therefore, the return to a great thinker in the process of rethinking ontology, epistemology, and methodology could save us from advancing an imitation of the West.

It has been almost two years since that first meeting and the question of how to resist the dominance of Western knowledge still remains a puzzle for me as an IR student. At the time of reading on Ibn al- 'Arabi and writing this paper, my conviction was that freeing ourselves from non-Western thinkers' "tragedy", according to which only Europe is theoretically knowable and all other histories are only matters of empirical research, ${ }^{64}$ is possible only when we recall the pre-modern sources. In other words, the most plausible way of superseding the Western mode of thought is to return to the authentic texts prior to the domination of Western philosophy. This conviction, however, ignores power relations between the West and the rest, through which all modes of knowledge have been embedded in Eurocentric metanarratives. For example, the question of why non-Western intellectuals seek approval from the Western academy ${ }^{65}$ is greatly related to existing power relations. This fact explains both how non-Western intellectuals keep failing to develop an alternative theory and why reading pre-modern texts is perpetually interrupted.

What is the use then of reading/remembering Ibn al- Arabi in developing an alternative mode of thought in social science in general and IR in particular? If the Westernness of IR as shaping what can/not be said is a reality of our time, how is the non-Western voice is to be heard? For Mustapha Kamal Pasha, all attempts to recover the past necessarily result in "naturalizing Western IR as IR", since the Western mode of thought conditions IR's "horizon of alternative". ${ }^{66}$ "The non-West is not permitted to generate narratives of universality" because it can attain "presence only by conceding its alterity or by surrendering its distinctiveness" ${ }^{67}$ In short, the Western mode of thought lets others speak only when their voice is consumable. If so, a question arises: Is our voice audible if it does not tell a story about the non-Western world to the Western audience? To my wit, that answer lies at the very logic of how a specific mode of thought dominates others.

As Edward Said argues, the will to power of the West over the non-West resulted in nonWestern silence and Western writing. ${ }^{68}$ In other words, the domination of Western thought over the rest is possible only because non-Western thought has been forced into silence by the

\footnotetext{
${ }_{63}$ Martin Heidegger, “'Only a God Can Save Us': Der Spiegel Interview with Martin Hedegger (1966)," in The Heidegger Controversy: A Critical Reader, ed. Richard Wolin (the U.S.: MIT Press, 1993), 106.

${ }_{64}$ Dipesh Chakrabarty, "Postcoloniality and the artifice of history: who speaks for 'Indian' pasts?" Representations 37 (1992): 3; Mustapha Kamal Pasha, "Untimely Reflections," In International Relations and Non-Western Thought, ed. Robbie Shilliam (London \& New York: Routledge, 2011), 218.

${ }_{65}$ See, Ersel Aydınlı and Julie Mathews, "Periphery Theorising for a Truly Internationalised Discipline: Spinning IR theory out of Anatolia," Review of International Studies 34, no. 4 (2008): 711-12.

${ }_{66}$ Pasha, "Untimely Reflections," 218.

67 Ibid.

68 Edward Said, Orientalism (London: Penguin Classics, 2003), 94.
} 
processes of prohibition and alienation. If Said is right, it is certain that the very possibility of "Western thought" is the silence of the non-Western one. Then, the "mechanisms of exclusion" are the main issues at this point, because is the absolute limit of Western hegemonic thought is driven out. ${ }^{69}$ To put it differently, the silence of non-Western thought takes part in the formation of Western thought by being "an element that functions alongside the things said, with them and in relation to them within over-all strategies... an integral part of the strategies that underlie and permeate" the Western thought. ${ }^{70}$

To clarify the role of silence in the construction of specific thought, Ibn al- 'Arabi's idea on the function of the alif - the first letter of the Arabic alphabet - in language is useful. When he attempts to explain the importance of the alif for the other letters, he points out the absence/silence of the alif, which is utterly immanent in other letters. For him, the alif is silent when other letters speak. The alif is implicitly present in every letter because "the letters are regulated by the alif and the alif always accompanies them". ${ }^{71}$ Because the alif is the foundation of all the letters, it makes the totality of the letters possible. Moreover, the "alif is not from letters" and "does not break down into them" while "all letters may be broken down into and built up from it". ${ }^{72}$ Although the alif is absent within other letters, it is the foundation of their existence. ${ }^{73}$ Like the alif, the very possibility of Western thought is the silent existence of non-Western within the Western. Therefore, my conviction is not a futile attempt; recalling silenced non-Western texts is the only way to challenge the dominance of Western thought. Otherwise, what remains at hand is to live in a colonial mode of thought.

Unfortunately, most existing IR studies in Turkey, including mine, are reduced to "a reservoir of data production to illuminate the validity of Western thought". ${ }^{74}$ The transition, at least "from imitation to hybridity", ${ }^{75}$ for Turkish IR (or social science) is possible only when Turkish scholars are able to read current hegemonic IR theories together with non-Western texts. For example, reading Jacques Derrida, Judith Butler, or other poststructuralist names with Ibn al- 'Arabi is very productive in creating a "new" hybrid (or alternative) theory. For the case of IR, reading existing theories together with non-Western texts will save IR from Western hegemonic thought and make it international. ${ }^{76}$ Since forgetting what we learn from the Western intellectual tradition is impossible, ${ }^{77}$ the only viable alternative is remembering the non-Western mode of thought simultaneously. However, "reading together with" is not an easy task.

\footnotetext{
${ }_{69}$ Michel Foucault, The History of Sexuality: An Introduction, Translate: Robert Hurley (New York: Vintage Books, 1990), 27.

70 Ibid.

71 Muhyiddin Ibn Arabi, Contemplation of the Holy Mysteries, trans. Cecilia Twinch and Pablo Beneito (Oxford: Anqa Publishing, 2008), 55.

72 Quoted by Mohamed Haj Yousef, Ibn 'Arabi': Time and Cosmology (New York: Routledge, 2008), 181.

73 This idea is echoed in Rabbi Mendel's (d. 1814) comments on the Aleph, the first letter of Hebrew alphabet. For him, while the Aleph is "the spiritual root of all other letters", it is silent in everything. It is so, because the Aleph is "the preparation for all audible language, but in itself contains no determinate, specific meaning". See, Gershom Scholem, On the Kabbalah and its Symbolism (The United States of America: Schocken Books, Scholem, 1996), 30.

${ }_{74}$ Pasha, "Untimely Reflections," 218.

75 Ibid.

${ }_{76}$ Arlene B. Tickner and David L. Blaney, Claiming the International: Worlding Beyond the West (London: Routledge, 2013).

77 According to a famous story, the method used by master Iranian poets in teaching their pupils had three phases: First, memorize all the poems of a famous poet, which is not such a hard task. Second, forget all the poems you memorized, which is the real challenge. Third, if you are able to pass this phase, start writing your own poems.
} 


\section{Bibliography}

Acharya, Amitav. "Dialogue and Discovery: In Search of International Relations Theories Beyond The West." Millenium: Journal of International Studies 39, no. 3 (2011): 619-37.

Acharya, Amitav, and Barry Buzan. "Why is There No Non-Western International Relations Theory? An Introduction." International Relations of the Asia-Pacific 7, no. 3 (2007): 287-312.

Almond, Ian. Sufism and Deconstruction: A Comparative Study of Derrida and Ibn'Arabi. London: Routledge, 2004.

Aydınl, Ersel, and Julie Mathews. "Periphery Theorising for a Truly Internationalised Discipline: Spinning IR Theory Out of Anatolia." Review of International Studies 34, no. 4 (2008): 693-712.

Behera, Navnita Chadha. "Re-imagining IR in India." International Relations of the Asia-Pacific 7, no. 3 (2007): 341-68.

Biltekin, Gonca. "Batı-dışı Uluslararası İlişkiler Teorileri ve Özgün Kuram.” In Uluslararası İlişkiler Teorileri, edited by Ramazan Gözen, 517-64. İstanbul: İletişim, 2014.

Chakrabarty, Dipesh. "Postcoloniality and the Artifice of History: Who Speaks for 'Indian' Pasts?” Representations 37 (1992): 1-26.

Chittick, William C. The Sufi Path of Knowledge: Ibn al- 'Arabi's Metaphysics of Imagination. Albany: Suny Press, 1989.

Crawford, Robert M.A. "Where Have All Theorists Gone- Gone to Britain? Everyone? A Story of Two Parochialisms in International Relations.” In International Relations-Still an American Social Science?: Toward Diversity, edited by Robert M.A. Crawford and Darryl S.L. Jarvis, 221-42. Albany: SUNY University Press, 2001.

Foucault, Michel. The History of Sexuality: An Introduction. Translated by Robert Hurley. New York: Vintage Books, 1990.

Haj Yousef, Mohamed. Ibn 'Arabi': Time and Cosmology. New York: Routledge, 2008.

Heidegger, Martin. “'Only a God Can Save Us': Der Spiegel Interview with Martin Hedegger (1966).” In The Heidegger Controversy: A Critical Reader, edited by Richard Wolin, 91-116. U.S.: MIT Press, 1993.

Hoffmann, Stanley. “An American Social Science: International Relations.” Daedalus 106, no. 3 (1977): 41-60.

Holsti, Kal J. The Dividing Discipline. Winchester, Mass.: Allen \& Unwin, 1985.

Ibn al-'Arabī. The Bezels of Wisdom. Translated by Ralph Austin. New Jersey: Paulist Press, 1980.

Ibn Arabi, Muhyiddin. Contemplation of the Holy Mysteries. Translated by Cecilia Twinch and Pablo Beneito. Oxford: Anqa Publishing, 2008.

--- . Fütuhat-ı Mekkiye. Translated by Ekrem Demirli. 18 vols. Istanbul: Litera Yayınc1lık, 2006-2012.

Norbu, Dawa. "Tibet in Sino-Indian Relations: The Centrality of Marginality." Asian Survey 37, no. 11 (1997): 1078-95.

Pasha, Mustapha Kamal. "Untimely Reflections." In International Relations and Non-Western Thought, edited by Robbie Shilliam, 217-26. London \& New York: Routledge, 2011.

Said, Edward. Orientalism. London: Penguin Classics, 2003.

Scholem, Gershom. On the Kabbalah and Its Symbolism. The United States of America: Schocken Books, Scholem, 1996.

Smith, Tony. "Requiem or New Agenda for Third World Studies." World Politics 37, no. 4 (1985): 532-62.

Spivak, Gayatri C. "Can the Subaltern Speak?" In Marxism and the Interpretation of Culture, edited by C. Nelson and L. Grossberg, 217-313. Champaign, IL: University of Illinois Press, 1988.

Tickner, Arlene B. and David L. Blaney. Claiming the International: Worlding Beyond the West.London: Routledge, 2013.

Wiarda, Howard. "The Ethnocentrism of the Social Science: Implications for Research and Policy." The Review of Politics 43 (1981): 163-97.

Wæver, Ole. "The Sociology of a Not So International Discipline: American and European Developments in International Relations.” International Organization 52, no. 4 (1998): 687-727.

Xuetong, Yan. Ancient Chinese Thought and Modern Chinese Power. New Jersey: Princeton University Press, 2011.

--- "Xun Zi’s Thoughts on International Politics and Their Implications." Chinese Journal of International Politics 2, no. 1 (2008): 135-65. 